\title{
OPTIMIZATION OF ENCAPSULATION EFFICIENCY AND LACTIC ACID BACTERIA VIABILITY THROUGH A COMBINATION BETWEEN CAPSULE AGENTS AND TOFU WASTE PREBIOTIC
}

\author{
Virna Muhardina ${ }^{1, *}$, Putri Meutia Sari ${ }^{1}$, Yuliani Aisyah ${ }^{2}$, Sri Haryani ${ }^{2}$ \\ and Said Ali Akbar ${ }^{3, *}$ \\ ${ }^{1}$ Department of Agricultural Industrial Technology, Universitas Serambi Mekkah, 23245, \\ Aceh, Indonesia \\ ${ }^{2}$ Department of Food Technology, Agriculture Faculty, Universitas Syiah Kuala, 23111, \\ Aceh, Indonesia \\ ${ }^{3}$ Department of Chemical Education, Universitas Serambi Mekkah, 23245, Aceh, Indonesia \\ *E-mail: virna.muhardina@serambimekkah.ac.id; said.aliakbar@serambimekkah.ac.id
}

\begin{abstract}
Here, we reported the effect of different variety of capsule agents (alginate and carrageenan) and concentration of prebiotic (tofu waste) on the viability of probiotics and the effectiveness of encapsulation. This study explored the feasibility of combination at normal and low $\mathrm{pH}$. The carrageenan displayed better capsule agents rather than alginate at normal conditions and simulated gastric acid. This phenomenon was proved by the protection capability towards probiotic vegetative cells with a total of $9.96 \mathrm{log}$ CFU/gram and $96.4 \%$ encapsulation efficiency under normal conditions, and then $4.23 \mathrm{log} \mathrm{CFU} / \mathrm{gram}$ and $41 \%$ effectiveness of encapsulation at $\mathrm{pH} 2$. Moreover, the combination of carrageenan and $3 \%$ prebiotic can maintain the viability of lactic acid bacteria about $10.17 \mathrm{log}$ $\mathrm{CFU} /$ gram and $4.33 \mathrm{log} \mathrm{CFU} / \mathrm{gram}$ in normal and acidic conditions respectively, with encapsulation effectiveness about $98.43 \%$ and $41.9 \%$ according to those tested conditions.
\end{abstract}

Keywords: Alginate, Carrageenan, Tofu, Lactic Acid Bacteria, Encapsulation.

(C) RASĀYAN. All rights reserved

\section{INTRODUCTION}

Probiotics are living microorganisms that can provide health benefits to humans, especially in the digestive tract. Lactic acid bacteria (LAB), such as Lactobacillus sp. included in the probiotic group, are the most common types of probiotic bacteria used in food products. ${ }^{1}$ The bacterial cell needs to be alive in the human intestine in order to deliver its therapeutic effects and functional properties in improving health and reducing the risk of diseases. ${ }^{2}$ Therefore, the viability or survival condition of probiotic cells is very important to note.

As probiotic bacteria, Lactobacillus bulgaricus has a specific condition for growth and proliferation, which are temperature $30-40^{\circ} \mathrm{C}$ and $\mathrm{pH}$ about $4-5 .^{3}$ In terms of $\mathrm{pH}$, it is not proper with the acid situation in stomach having $\mathrm{pH}$ approximately 1.5-2. ${ }^{4}$ Inappropriate living condition can destruct bacterial cell, diminish its survival, and cause the death of bacteria.

Encapsulation is a solution that can be implemented to coat and protect probiotic cells from the improper condition. This method ensures the survival of the living cell and delivers it into the intestinal tract. ${ }^{5}$ Encapsulation produces hydrocolloid beads with size ranging from nanometers to millimeters. The capsulation process can improve bacterial cell viability during in human stomach, its stability and its effectiveness of functional benefits in health. $6,7,8$

Rasayan J. Chem., 13(1), 240-244(2020)

http://dx.doi.org/10.31788/RJC.2020.1315569

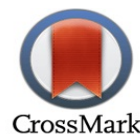


RASĀYAN J. Chem.

Vol. 13 | No. 1 | 240 - 244| January - March | 2020

The formation of the capsule is determined by the type of encapsulating material. There are several types of materials, such as inulin, starch, chitosan, milk protein, alginate, and carrageenan. ${ }^{8}$ Alginate and carrageenan are polysaccharides that are extracted from algae or seaweed. Both of these capsule agents have the ability to form gels with different molecular components. Alginate structure is heterogeneous consisting of mannuronic and guluronic acid, while carrageenan is composed of galactose. ${ }^{9}$ The differences may affect the condition of the capsule. In addition, the viability of probiotic bacteria can be supported by adding prebiotics, such as solid waste of tofu production. Its oligosaccharide is considered a prebiotic source. ${ }^{10}$

Encapsulation probiotic in this study used a combination of a variety of encapsulating materials and different concentrations of tofu waste as prebiotic with extrusion technique. It aims to comprehend the effect of the type of capsule agents and the concentration of prebiotic on probiotic viability and encapsulation efficiency in a normal and acid condition.

\section{EXPERIMENTAL}

\section{Tools And Materials}

The ingredients used in this research were Lactobacillus bulgaricus strains, carrageenan, alginate, MRS agar and broth (Merck), $\mathrm{KCL}$ and $\mathrm{CaCl}_{2}$. The tools used were digital scales, laminar flow cabinets (Bassaire Model 04HB; Astecair 3000L), incubators (Eyela Personal Incubator SLI-170D; Eyela Soft Incubator SLI-450N), centrifuge (Hettich Zentrifugen EBA 20), water bath (Memmert), thermometer, and glassware. It also required syringes for the encapsulation process.

\section{Research Design}

This study used a Completely Randomized Design (CRD) consisting of two factors: capsule agents (alginate and carrageenan) and the percentage of tofu waste flour $(1.5 \%, 2 \%, 2.5 \%$, and $3 \%)$. The data obtained were processed statistically using ANOVA.

\section{Making of Tofu Waste Flour}

Solid waste of tofu was pressed using a hydraulic press. Then the waste was steamed for \pm 15 minutes and dried by the sun-drying method for 8 hours per day. The drying process was done up to \pm 3 days. Dried waste was ground and sieved with 140 mesh size to produce flour.

\section{Preparation of Probiotic Capsule}

The pellet of L. bulgaricus was dissolved into distilled water to be used as a culture solution. The encapsulating solution made from carrageenan and alginate were homogenized and sterilized. This solution was mixed with tofu waste flour following the concentration of treatment. Bacterial culture and encapsulating solutions were mixed with a ratio of 1: 4. This mixture was extruded using a syringe into $\mathrm{KCL}$ and $\mathrm{CaCl}_{2}$ liquid as hardener solutions. Probiotic capsule was stored in a refrigerator. ${ }^{11,12}$

\section{RESULTS AND DISCUSSION}

The survival of probiotic bacteria can be enhanced by coating bacterial cells using encapsulating materials such as alginate and carrageenan. Fig.-1 shows the viability of Lactobacillus bulgaricus assessed in total lactic acid bacteria (LAB) and the effectiveness of encapsulation. Total LAB is the number of bacteria that survive in the tested conditions. At normal $\mathrm{pH}$, the amount of LAB in alginate and carrageenan capsules tends to be similar, as they have equivalent logarithmic numbers (10 log CFU/gram). However, at low $\mathrm{pH}$, there is a decrease of LAB about $6 \log$. Based on the data, carrageenan is more effective as capsule material as it has a better capability to protect LAB cells in the capsule. This is indicated by the higher number of LAB in carrageenan capsules (4.2 log CFU/gram) compare to alginate capsules (3.9 log CFU/gram) with the difference about $1 \mathrm{log}$. Carrageenan has a high molecular weight of about 700-1000 $\mathrm{kDa}$ related to a high number of hydroxyl and sulphate groups. It performs better hydrophilic characteristic and forms a thicker layer and more viscous gel. ${ }^{13}$ Conversely, alginate containing only 300 $\mathrm{kDa}$ molecular weight forms a thinner layer with semipermeable characteristics, more porosity and lower 
RASĀYAN J. Chem.

Vol. 13 | No. 1 |240 - 244| January - March | 2020

protection in acid condition ${ }^{6,14}$ which responsible to the cells damaging and death due to interaction with acid media ( $\mathrm{pH}$ 2).

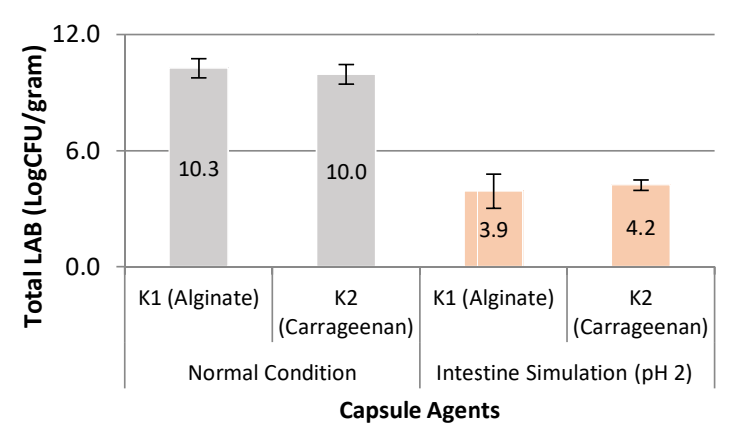

(a)

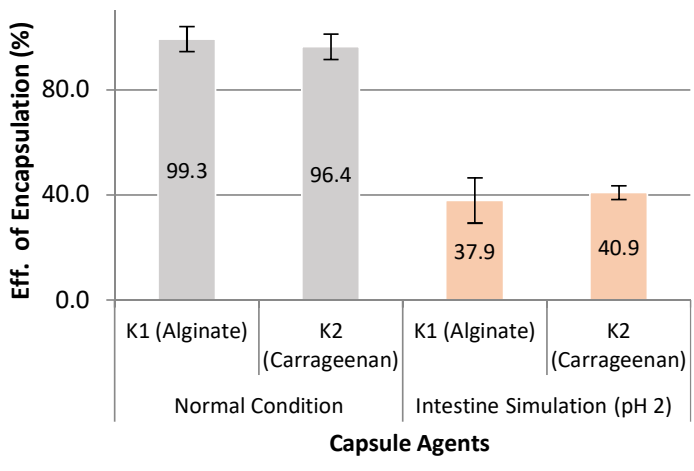

(b)

Fig.-1: (a) Total Lactic Acid Bacteria (LAB); (b) Effectiveness of Encapsulation of Probiotic Capsules with Variety of Capsule Agents pH Comparison

Effectiveness of encapsulation is the percentage of the capsule's capability to protect bacterial cells calculated based on the comparison between a number of bacteria living in the capsule and the number of initial bacteria before being encapsulated. ${ }^{15}$ The effectiveness of encapsulation in normal $\mathrm{pH}$ does not show a significant difference, in which carrageenan had slightly lower encapsulation effectiveness compares to alginate, around $3 \%$. However, encapsulation using carrageenan is more effective and more efficient in protecting bacterial cells at $\mathrm{pH} 2(41 \%)$ than alginate $(38 \%)$. This condition is preferred because the viability of LAB in high acid media ensures its cells may still survive in the human intestinal tract.

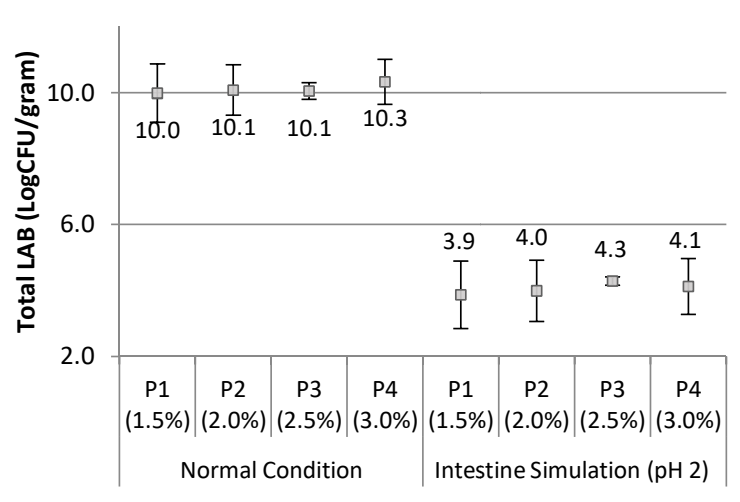

Prebiotic Concentrations

(a)

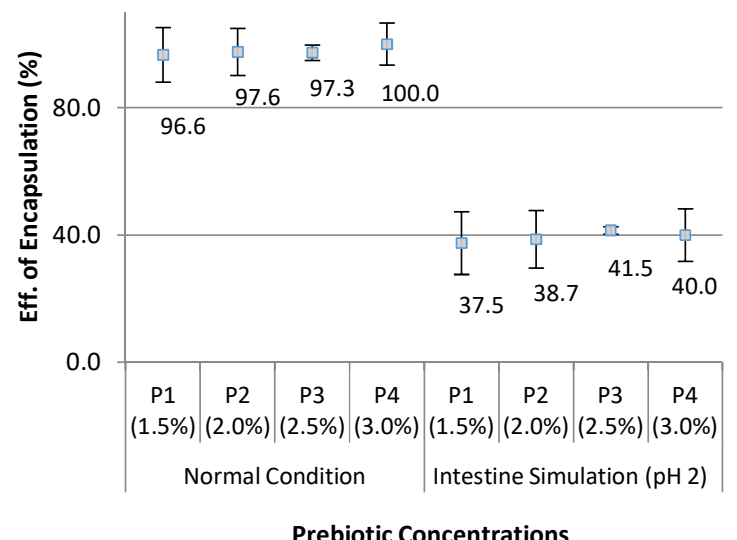

(b)

Fig.-2: (a) Total Lactic Acid Bacteria (LAB); (b) Effectiveness of Encapsulation of Probiotic Capsules with Different Prebiotic (Tofu Waste Flour) Concentrations

The addition of prebiotic (tofu waste flour) is predicted may improve the viability of probiotic. Figure-2 shows a comparison between total LAB and encapsulation efficiency with the effect of using tofu waste flour as a source of nutrition (prebiotics). On both charts, they demonstrate that at normal $\mathrm{pH}$, they reach maximum growth condition of LAB compared to the condition in low $\mathrm{pH}$. The reduction of LAB viability in $\mathrm{pH} 2$ reaches about 6 logarithms or 55\% encapsulation efficiency.

Moreover, the data figures out that the concentration of prebiotic (tofu waste flour) affects the improvement of LAB survival in any living condition. The use of tofu waste flour at a maximum percentage (3\%) can increase the life resistance of LAB in capsules which is around $10.3 \log \mathrm{CFU} / \mathrm{gram}$ with $100 \%$ encapsulation effectiveness at normal $\mathrm{pH}$ and $4.1 \log \mathrm{CFU} / \mathrm{gram}$ with $40 \%$ effectiveness at $\mathrm{pH}$ 
RASĀYAN J. Chem.

Vol. 13 | No. 1 | 240 - 244| January - March | 2020

2. It confirms the advantage of tofu waste in providing nutrition, which are oligosaccharides, protein, fiber as a source of energy for LAB and supporting its growth either in common or severe condition. ${ }^{16}$

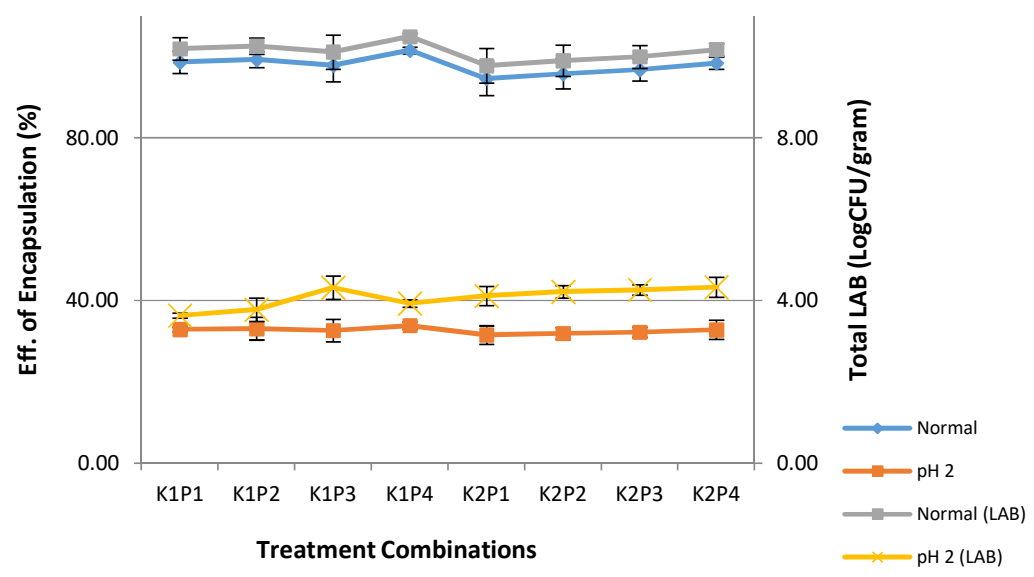

Fig.-3: Comparison between Total LAB and Encapsulation Efficiency in Neutral and Acid Conditions in All Treatment Combinations

A comparison of total LAB and the effectiveness of encapsulation in all samples can be seen in Figure 3 . In both tests, it demonstrates that the two encapsulating materials have similar encapsulation effectiveness and protection capabilities at normal $\mathrm{pH}$. The extrusion encapsulation method which is carried out in this study can maintain up to $4 \log$ CFU/gram LAB cells under acid condition. This number is still lower than the requirement for a sufficient amount of probiotic that must be present in the human digestive tract. However, this number indicates that even in using the simplest encapsulation method, it is still able to maintain the viability of probiotic bacteria with $\pm 40 \%$ efficiency. In addition, the overall samples tested show an increasing trend of total LAB when adding tofu waste flour to a maximum percentage.

The optimal conditions of encapsulation method combined with variations of encapsulating materials and concentration of tofu waste flour can also be considered from the reduction percentage of LAB living cells and encapsulation efficiency in two different $\mathrm{pH}$ situations. The smaller the number of LAB survive or encapsulation efficiency reduction, the more effective the treatment combination.

Table-1: Reduction of LAB and encapsulation efficiency regarding Type of Capsule Agents and Prebiotic Concentrations Due to High Acidity

\begin{tabular}{cc}
\multicolumn{2}{c}{ Concentrations Due to High Acidity } \\
\hline Treatments & Reduction (\%) \\
\hline Capsule Agents $(\mathrm{K}):$ & 61.8 \\
Alginate $\left(\mathrm{K}_{1}\right)$ & 57.5 \\
Carrageenan $\left(\mathrm{K}_{2}\right)$ & \\
Tofu Waste Conc. $(\mathrm{P}):$ & 61.2 \\
Prebiotic 1.5\% $\left(\mathrm{P}_{1}\right)$ & 60.4 \\
Prebiotic 2.0\% $\left(\mathrm{P}_{2}\right)$ & 57.3 \\
Prebiotic 2.5\% $\left(\mathrm{P}_{3}\right)$ & 60.0 \\
Prebiotic 3.0\% $\left(\mathrm{P}_{4}\right)$ & \\
Combination of treatments: & 64.4 \\
$\mathrm{~K}_{1} \mathrm{P}_{1}($ Alg + Preb 1.5\%) & 63.2 \\
$\mathrm{~K}_{1} \mathrm{P}_{2}($ Alg + Preb 2.0\%) & 57.3 \\
$\mathrm{~K}_{1} \mathrm{P}_{3}(\mathrm{Alg}+$ Preb 2.5\%) & 62.5 \\
$\mathrm{~K}_{1} \mathrm{P}_{4}($ Alg + Preb 3.0\%) & 57.9 \\
$\mathrm{~K}_{2} \mathrm{P}_{1}($ Car + Preb 1.5\%) & 57.4 \\
$\mathrm{~K}_{2} \mathrm{P}_{2}($ Car + Preb 2.0\%) & 57.3 \\
$\mathrm{~K}_{2} \mathrm{P}_{3}($ Car + Preb 2.5\%) & 57.4 \\
$\mathrm{~K}_{2} \mathrm{P}_{4}($ Car + Preb 3.0\%) & \\
\hline
\end{tabular}


RASĀYAN J. Chem.

Vol. 13 | No. 1 | 240 - 244| January - March | 2020

From Table 1 it can be seen that carrageenan shows a lower reduction value $(57.5 \%)$ than alginate (61.8\%). Similarly, once carrageenan combines with tofu waste flour, it occupies a small decline number. In addition, the use of tofu waste flour at an optimal percentage also showed a minor percentage of LAB mortality. It explains that the combination of carrageenan and tofu waste flour $3 \%$ provides optimal conditions for encapsulation process and survival of Lactobacillus bulgaricus (LAB) at low $\mathrm{pH}$ with an insignificant reduction number of the living cells, around $57 \%$ decrease.

\section{CONCLUSION}

Viability of LAB especially Lactobacillus bulgaricus and the effectiveness of encapsulation depend on the type of capsule agent and concentration of prebiotic (tofu waste flour) added into the capsule. Carrageenan is proper material for coating and protecting probiotic cells inside the capsule by maintaining a high number of living cells in normal and acidic conditions. A combination with a high concentration of tofu waste flour can enhance viability and encapsulation efficiency as well.

\section{ACKNOWLEDGMENT}

The author thanks to the Ministry of Research, Technology, and Higher Education (DIKTI) for financially supporting this research through Penelitian Kerjasama Antar Perguruan Tinggi (PKPT) program under contract number 061/LPPM-USM/KP/V/2018.

\section{REFERENCES}

1. L.S. Cock, V.V. Castillo, African Journal of Microbiology Research, 7, 4743(2013), DOI:10.5897/AJMR2013.5718

2. C.P. Champagne, A.G.d. Cruz, M. Daga, Current Opinion in Food Science, 22, 160(2018), DOI: $10.1016 /$ j.cofs.2018.04.008

3. R. Broadbent, R.L. Jeff, V. Larsen, J.L. Deibel, Journal of Bacteriology, 192, 2445(2010), DOI: $10.1128 \% 2 F J B .01618-09$

4. G.S. Rutella, D. Tagliazucchi, L. Solieri, Food Microbiology, 60, 54(2016), DOI:10.1016/j.fm.2016.06.017

5. M.K. Tripathi, S.K. Giri, Journal of Functional Foods, 9, 225(2014), DOI:10.1016/j.jff.2014.04.030

6. K. Kailasapathy, Current Issues in Intestinal Microbiology. 3, 39(2002)

7. H. Ozyurt, S. Otles, Acta Scientiarum Polonorum Technologia Alimentaria, 13(4), 413(2014), DOI: $10.17306 / J . A F S .2014 .4 .8$

8. F.B. Haffner, R. Diab, A. Pasc, AIMS Material Science, 3(1), 114(2016), DOI: 10.3934/matersci.2016.1.114

9. S.A. Akbar, E. Satria, Rasayan Journal Of Chemistry, 12(3), 1212(2019), DOI: $10.31788 /$ RJC.2019.1235370

10. L. Zhang, Y. Lou, M.A.I. Schutyser, Food Structure, 18, 14(2018), DOI: 10.1016/j.foostr.2018.10.002

11. C.L. Tien, M. Millette, M.A. Mateescu, M. Lacroix, Biotechnology and Applied Biochemistry, 39, 347(2004), DOI:10.1042/BA20030158

12. W.C. Lian, H.C. Hsio, C. Chou, Journal of Food Microbiology, 74, 79(2002), DOI:10.1016/S01681605(01)00733-4

13. M.F. Bambace, M.V. Alvarez, M.D.R. Moreira, Food Research International, 122, 653(2019), DOI: 10.1016/j.foodres.2019.01.040

14. P. Montero, M. Pérez-Mateos, 16, 375(2002), DOI:10.1016/S0268-005X(01)00110-2

15. A. Adrianto, Encapsulation of Lactobacillus casei with extrusion technique in curd milk production" Thesis, Agricultural Institute, Bogor, 2011.

16. A. Manzoor, A. Tayyeb, Microbial Pathogenesis, 131, 22(2019), DOI: 10.1016/j.micpath.2019.03.016

[RJC-5569/2019] 